\title{
BAHASA IKLAN DI ANTARA EROTISME DAN SIMBIOSIS MUTUALISME
}

Advertising Language Between Eroticism and Mutualism Symbiosis

\author{
Abdul Rahman Rahim, Arifuddin, Wardiman \\ Universitas Muhammadiyah Makassar \\ rahman@unismuh.ac.id
}

Naskah Diterima Tanggal 1 Februari 2020_Direvisi Akhir Tanggal 27 Februari 2021_Disetujui Tanggal 14 Juni 2021 doi: https://doi.org/10.26499/rnh.v10i1.3366

\begin{abstract}
Abstrak
Masalah utama yang dibahas dalam penelitian ini adalah pemakaian bahasa di media iklan sebagai salah satu bentuk pemakaian bahasa Indonesia di ruang publik. Melalui promosi lewat iklan, sebuah produk dapat dikenal oleh masyarakat dan inilah yang menjadi tujuan sebuah produk diiklankan. Pendekatan yang digunakan dalam penelitian ini adalah pendekatan kualitatif yakni penelitian yang menghasilkan data deskriptif berupa kata-kata lisan atau tertulis dari orang atau prilaku yang diamati. Aspek yang dideskripsikan adalah hasil analisis pemakaian bahasa vulgar dan makna yang terkandung dalam setiap iklan. Berdasarkan hasil analisis terhadap beberapa produk yang diiklankan, baik di media elektronek (televisi) maupun di media sosial terbukti bahwa pilihan kata yang bersifat erotis digunakan dalam media iklan.
\end{abstract}

Kata-kata kunci: erotisme, iklan, simbiosis mutualisme

\begin{abstract}
The main problem discussed in this study is the use of language in advertising media as a form of using Indonesian in public spaces. Through promotion through advertising, a product can be known by the public and this is the purpose of an advertised product. The approach used in this study is a qualitative approach, namely research that produces descriptive data in the form of spoken or written words from people or observed behavior. The described aspect is the result of an analysis of the use of vulgar language and the meaning contained in each advertisement. Based on an analysis of several advertised products, both on electronic media (television) and on social media, it is evident that erotic word choices are used in advertising media.
\end{abstract}

Keywords: eroticism, advertising, mutualism symbiosis

How to Cite: Rahim, Abdul Rahman, Arifuddin, dan Wardiman. (2021). Bahasa Iklan di Antara Erotisme dan Simbiosis Mutualisme. Ranah: Jurnal Kajian Bahasa. 10(1). 205-215. doi: https://doi.org/10.26499/rnh.v10i1.3366

\section{PENDAHULUAN}

Permasalahan tentang karakter bangsa telah menjadi wacana yang bersifat Nasional. Ketika putra- putri generasi penerus bangsa yang terjerumus ke hal-hal yang negatif, maka banyak pihak yang menuding rendahnya kualitas karakter bangsa sebagai efek dari rendahnya kualitas pendidikan. Akhirnya tudingan menohok ke dada para guru maupun dosen karena dinilai tidak mampu menjadikan anak bangsa sebagai generasi yang dapat diandalkan. Sebenarnya tidak bijak jika kegagalan terhadap penanaman karakter bangsa ditimpakan kepada guru dan dosen 
saja karena banyak unsur yang terlibat di dalam penciptaan generasi bangsa yang berkarakter. Demikian pula sebaliknya, kita tidak boleh menafikan pengaruh negatif dari kemajuan teknologi sehingga beban dan tanggung jawab tenaga pendidik semakin berat (Hapsah, 2013). Contoh sederhananya adalah alat komunikasi seperti gawai yang tidak hanya berfungsi sebagai alat untuk berkomunikasi tetapi juga dapat dijadikan sarana untuk mempromosikan sebuah barang atau jasa melalui media iklan. Di dalam kajian psikologi pendidikan diuraikan bahwa iklan yang sering memunculkan gambar-gambar atau kata-kata yang erotis dapat merusak mental dan pola pikir anak-anak dan remaja (Aprilia, 2005).

Uraian di atas menguatkan bahwa keberadaan bahasa sangat berperan terhadap sebuah iklan.Dengan media bahasalah sehingga pesan-pesan dapat disampaikan lewat sebuah iklan. Masyarakat membutuhkan sebuah iklan, begitu pula sebaliknya, iklan membutuhkan masyarakat sebagai konsumennya. Iklan telah menjadi bagian dari kehidupan sehari-hari yang kehadirannya ada di segala ruang dan waktu. Masyarakat pun akan terbantu dengan adanya iklan karena dapat memiliki informasi berbagai produk sebelum melakukan transaksi pembelian. Menurut Hapsah. M (2012) iklan dapat didefinisikan sebagai kegiatan promosi barang atau jasa lewat media massa. Atau suatu bentuk komunikasi yang dimaksudkan untuk merepresentasikan kualitas produk jasa dan ide berdasarkan kebutuhan konsumen (Sukma, 2018).

Pada dasarnya iklan ditayangkan dengan tujuan untuk memengaruhi masyarakat agar membeli atau mengkonsumsi produk yang telah ditawarkan. Itulah sebabnya perusahaan yang hendak mengiklankan produknya untuk dipasarkan kepada masyarakat, bersedia menyiapkan anggaran yang cukup besar demi kesuksesan produk yang diiklankan tersebut. Bahkan pihak perusahan bekerjasama dengan pihak pembuat jingle iklan dan penyedia bintang iklan agar produknya dapat diterima oleh masyarakat (Candrawati, 2019).

Mengacu kepada uraian di atas, dapat ditegaskan bahwa iklan sangat besar kontribusinya dalam memperkenalkan sebuah produk barang atau jasa kepada masyarakat. Hal ini berarti bahwa bahasa yang digunakan harus komunikatif, tidak bermkna ganda dan dapat dipahami secara saksama. Untuk itu pemilihan kosakata sangat berarti demi kesuksesan iklan tersebut. Septiani (2014) mengatakan bahwa pilihan kata merupakan satu syarat yang sangat penting dalam karang-mengarang dan dalam tutur setiap hari, sehingga perlu diperhatikan kaidah sosial pilihan kata itu Pemiihan kata tentu saja disesuaikan dengan makna yang dikandung oleh sebuah kata. Pemilihan kata juga harus sesuai dengan situasi dan tempat penggunaan kata-kata itu (Saputra, 2009). Kata yang tepat akan membantu seseorang mengungkapkan dengan tepat apa yang ingin disampaikannya, baik lisan maupun tulisan (Winata, 2012).

Dalam pembuatan sebuah jingle iklan, tentu tidak terlepas dari pemilihan kosakata yang menarik sehingga dapat menarik perhatian konsumen. Wujud iklan dapat berupa gambar, foto, dan kata-kata bahkan gabungan dari keduanya (Ireneus Lyon Yuniman Bagut, 2019). Namun banyak iklan di media massa cetak dan elektronik, maupun di media sosial yang menggunakan kosakata yang tidak sopan bahkan berkmakna erotisme sebagai salah satu starategi menarik perhatian para penonton atau yang menyaksikan iklan tersebut. Fenomena ini berada pada dua sisi yang berseberangan. Di satu sisi, pemakaian bahasa yang erotis tersebut tidak layak ditayangkan di media massa karena banyak anak-anak ataupun remaja yang menyaksikan tayangan iklaan tersebut, namun di sisi lain ada pihak yang meraup keuntungan dengan pemakaian bahasa semacam itu. Makalah singkat ini akan menyoroti penggunaan kata yang yang bermakna erotis di ruang publik, khususnya pada ragam iklan tema ini menarik dikaji karena terkesan bahwa kata-kata yang erotis dalam iklan tersebut ibarat simbiosis mutualisme (Aziz, 2010). 


\section{LANDASAN TEORI}

Bahasa sangat besar perannya dalam mempromosikan sebuah produk baik dalam bentuk barang maupun jasa. Dengan bahasa, produk tersebut dapat diketahui oleh masyarakat pemakaianya. Iklan ibarat Sebelum menjawab dari beberapa rumusan masalah tersebut, maka dijelaskan terlebih dahulu tentang pengertian iklan. Menurut Aprilia (2005) iklan adalah segala macam bentuk penyajian dan promosi ide, barang atau jasa non-personal yang dibayar oleh sponsor tertentu. Sedangkan menurut Kristiani (2017) periklanan adalah komunikasi nonpersonal yang dibayar oleh pihak sponsor yang menggunakan media massa untuk membujuk dan mempengaruhi audiensi.

Kerangka teori, penelitian ini menggunakan teori fungsi persuasif. Teori fungsi persuasif bahasa adalah teori yang digunakan dan mungkin untuk menjawab permasalahan dalam iklan sebagai sebuah wacana yang tidak dapat dipisahkan dari tujuan utamanya, yakni menjual (sell). Fungsi utama secara dominan dimanfaatkan untuk mendukung fungsi utama iklan, yakni fungsi persuasif bahasa seperti telah disinggung secara implisit oleh peneliti sebelumnya.

Dalam penelitian ini, dikemukakan dua pandangan mengenai teori fungsi bahasa, diantaranya Jakobson (1963) dan Leech (1974). Pandangan Jacobson tahun 1963 (Candrawati, 2019)) dikemukakan enam macam fungsi bahasa dan dimasukkan fungsi persuasif bahasa dengan istilah fungsi konatif sebagai pengungkap keinginan pembicara yang langsung atau segera dilakukan oleh penyimak. Dalam hal ini, bahasa digunakan untuk menunjukkan keterlibatan perhatian penerima pesan, dan juga untuk memengaruhi agar melakukan apa yang dianjurkan pengirim pesan. Fungsi konatif terutama ditandai oleh pemakaian kata ganti "Anda" atau "Anda sekalian", dan pemakaian bentuk kalimat perintah. Noth (1990:421) dalam bukunya Handbook of Semiotics juga menekankan bahwa keenam fungsi bahasa yang disampaikan Jakobson tersebut dalam model komunikasi ada pada iklan. Akan tetapi, fungsi konatif lebih banyak berperan. Selanjutnya, dikatakan bahwa fungsi fatik(phatic) sebagai pembuka, pemelihara hubungan atau kontak antar pembicara dan penyimak dan fungsi puitis(phoetic) sebagai penyandi pesan juga sangat menonjol dalam iklan.

Selanjutnya, pandangan Leech (Candrawati, 2019)) berbeda dengan pandangan yang dikemukakan oleh Jakobson diatas. Leech menggolongkan fungsi bahasa menjadi lima bagian, yaitu (1) fungsi informasional, yang berorientasi pada pokok persoalan,(2) fungsi ekspresif yang berorientasi pada pengungkapan perasaan dan sikap penuturnya, (3) fungsi direktif adalah fungsi yang digunakan untuk mempengaruhi perilaku atau sikap orang lain,atau berorientasi pada sasaran,seperti perintah dan permohonan, (4) fungsi estetik, sebagai pengganti istilah poetis yang digunakan dalam karya-karya sastra berorientasi pada pesan,dan (5) fungsi fatik adalah fungsi bahasa yang digunakan untuk menjaga agar hubungan komunikasi tetap terjaga.

Kedua pandangan tentang teori fungsi tersebut selanjutnya dipadukan dengan teori-teori lain untuk menggali kandungan makna persuasif wacana iklan sesuai dengan permasalahan yang dikaji. Teori-teori tersebut diterapkan secara ekliktik, meliputi(1) teori unsur bahasa tentang pertalian tema, diksi, referen bahasa (Candrawati, 2019); (2) kohesi wacana persuasif (Wulandari et al., 2019): (3) teknik-teknik komposisi wacana persuasif (Jaya \& Aceh, 2018) dan (4) pemahaman aspek konteks wacana persuasif tersebut yang diketengahkan oleh (Saputra, 2009) . Keempat teori tersebut dapat diuraikan masing-masing sebagai berikut.

Aspek unsur-unsur bahasayang terdapatpada stukturwacana iklan (tajuk, badan, dan penjelasan tambahan iklan) sebagai aspek pertama mengetengahkan beberapa unsur bahasa yang dominan yang berperan dalam menciptakan makna yang persuasif. Unsur-unsur itu meliputi tema, pilihan kata (diksi), referen,dan tindak ujar.Tema merupakan pokok yang ditonjolkan dalam iklan seperti "keunggulan", kemewahan", "dinamis", "ekonomis" dan"kepraktisan".Tema tersebut pada umumnya ditempatkan pada tajuk iklan dengan kreasi 
hurufnya yang besar dan tebal kemudian diuraikan dengan beberapa pernyataan pada bagian badan iklan untuk mendukung tema yang ditonjolkan dalam wacana tersebut (Hapsah, 2013).

Diksi mengandung pengertian sebagai teknik memilih kata yang tepat agar dapat menciptakan makna yang kongkret, oleh karena itu diperlukan rekayasa asosiatif (Yuliantini. T, 2019). Rekayasa asosiatif yang diperlukan khususnya pada kreasi wacana iklan sehingga pesan yang diakomodasikan oleh pilihan kata itu efektif. Pengetahuan diksi akan membantu pengiklan dalam menciptakanungkapan-ungkapan yang persuasif. Diksi yang baik mengandung pengertian teknis sebagai pilihan kata yang tepat dan efektif, artinya makna pilihan kata itu tidak mendekatiatau hampir mendekati tetapi benar-benar dapat membawa makna yang ingin disampaikan oleh pengiklan.

Di dalam periklanan, pilihan kata menjadi pertimbangan dalam berbagai aspek semantik sesuai dengan situasinya. Penggunaan properti-properti semantis tersebut dijumpai dalam wacana iklan dengan bahasa figuratif, seperti metafora, aliteration, paralelisme (Aniendya Christianna, 2012). Situasi yang dimaksud adalah (1) situasi yang mencakup jenis masalah yang dikemukakan dan apa tujuannya, serta khalayak sasarannya; (2) medan makna yang merupakan deretan kata dalam suatu paparan dengan kandungan makna yang saling berkaitan antara satu dengan yang lainnya, yang meliputi makna gramatika, makna konteks, makna denotatif, dan konotatif (Wahyuningratna \& Saputra, 2018).

Referen adalah objek yang diacu oleh simbol (verbal dan nonverbal) yang terlebih dahulu dikonsepsi oleh pemakai simbol itu. Candrawati mengemukakan (2019) menempatkan elemen referen itu sebagai elemen ketiga dalam suatu diagram segitiga (triangle diagram) yang dipersoalkan sebagai suatu diluar bahasa adalah prototype dari simbol atau nama tersebut.

\section{METODE PENELITIAN}

Pendekatan yang digunakan dalam penelitian ini adalah pendekatan kualitatif yakni penelitian yang menghasilkan data deskriptif berupa kata-kata lisan atau tertulis dari orang atau prilaku yang diamati. Aspek yang dideskripsikan adalah hasil analisis pemakaian bahasa vulgar dan makna yang terkandung dalam setiap iklan tersebut.

Subjek penelitian ini adalah kata-kata atau kalimat yang terdapat dalam iklan yang ditayangkan pada saluran televisi swasta yakni: TV One, RCTI, SCTV, Indosiar, ANTV, MNC TV, Trans TV, dan Global TV edisi tahun 2018--2019. Objek penelitian ini adalah pemakaian bahasa vulgar yang diucapkan oleh pemain atau bintang iklan yang disiarkan oleh media televisi swasta selama edisi tahun 2018-2019 di televisi. Data yang dikumpulkan dalam penelitian ini adalah bahasa vulgar dalam slogan iklan edisi tahun 2018--2019 di televisi dengan mencakup semua saluran televisi swasta di Indonesia edisi tahun 2018--2019, berupa pemakaian kata, frasa, atau kalimat yang mengandung unsur vulgar. Sumber data dalam penelitian ini adalah bahasa Indonesia ragam iklan yang ditayangkan di stasiun televisi swasta tahun 2018-2019.

Pengumpulan data dalam penelitian ini dilakukan dengan pengamatan dan catat. Artinya, data dalam penelitian ini diperoleh dengan cara mengamati iklan yang terdapat di televisi kemudian mencatat data iklan yang mengandung unsur vulgar. Pertama-tama iklan di televisi diamati, setelah itu dipilih iklan yang mengandung unsur vulgar. Saat teknik pengamatan berlangsung, peneliti melakukan pengamatan dengan keseriusan dan ketelatenan supaya didapatkan data yang akurat untuk melakukan penelitian mengenai bahasa vulgar.

Data penelitian ini dianalisis dengan menggunakan analisis makna, yaitu dengan membaca data yang telah ditemukan dalam pengamatan terhadap iklan di televisi, kemudian menerjemahkan bahasa iklan dengan sungguh-sungguh dan mengklasifikasikan data ke dalam pemakaian bahasa vulgar sesuai dengan teori yang ada.identifikasi data dilakukan untuk menetapkan data-data yang sudah terkumpul kemudian diklasifikasikan. Kemudian data dipilih mana yang akan dianalisis terlebih dahulu. Setelah terpilih data dianalisis kebahasaannya 
dengan cara menerjemahkannya secara makna. Setelah itu peneliti melakukan pembahasan lebih dalam dan menarik kesimpulan.

\section{PEMBAHASAN}

\section{Bahasa dan Iklan}

Bahasa sangat besar perannya dalam mempromosikan sebuah produk baik dalam bentuk barang maupun jasa. Dengan bahasa, produk tersebut dapat diketahui oleh masyarakat pemakaianya. Sedangkan iklan ibarat menjawab dari beberapa rumusan masalah tersebut, maka dijelaskan terlebih dahulu tentang pengertian iklan. Candrawati mengemukakan (2019) iklan adalah segala macam bentuk penyajian dan promosi ide, barang atau jasa non-personal yang dibayar oleh sponsor tertentu. Sedangkan menurut Septiani (2014) periklanan adalah komunikasi non-personal yang dibayar oleh pihak sponsor yang menggunakan media massa untuk membujuk dan mempengaruhi audience. Pengertian iklan seperti yang telah dikemukakan oleh para pakar di atas membuktikan bahwa bahasa sangat penting demi keberlangsungan sebuah iklan.

\section{Erotisme dalam Bahasa Iklan}

1. Iklan Pompa Air Shimizu

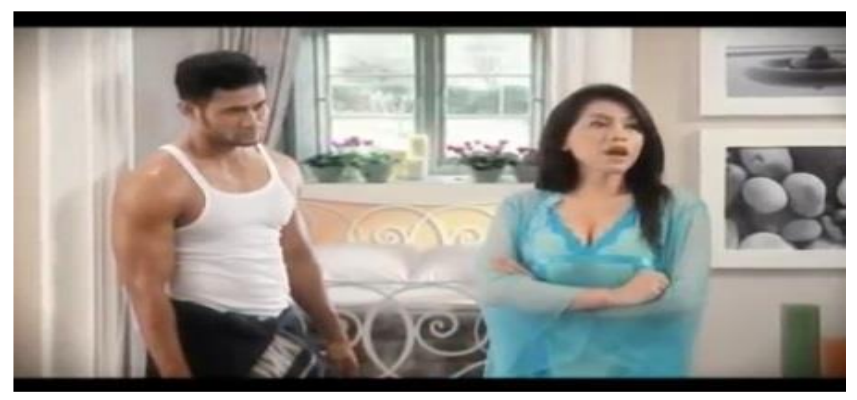

Gambar 1

Pada iklan ini dijelaskan bahwa pompa air merupakan kebutuhan paling vital, yang harus dipenuhi dalam sebuah rumah tangga untuk menjaga keharmonisan antara suami dan istri sehingga apabila tidak terpenuhi atau rusak maka sang istri akan merasa terganggu untuk mengerjakan pekerjaan rumah. Iklan ini menggambarkan bahwa salah satu rumah tangga tidak lagi harmonis akibat pompa air yang ada dirumahnya macet, sehingga sang istri marah kepada sang suami. Hal tersebut terlihat pada gaya bicara sang istri yang mencerminkan wajah tidak lagi sumringah, serta posisi badan yang membelakangi sang suami, ketika menyampaikan masalah pada pompa airnya yang tidak lagi mancur. Penekanan pada adegan ini adalah ketika sang istri menemukan pemecahan masalah dengan membeli pompa air yang berlabel "Shimizu".

Iklan ini sangat menonjolkan adegan yang mengarah ke hal-hal yang erotis hal tersebut terlihat jelas ketika produsen mendesign iklan ini dengan lebih memberikan porsi waktu yang banyak kepada pemeran perempuan untuk menunjukkan beberapa anggota tubuhnya yang seharusnya tidak patut untuk dipublikasikan, seperti adegan pada saat perempuan memakai baju tidur transparan warna biru dengan "area" lipatan buah dada terlihat. Selain pada gambar, ada beberapa penekanan kata yang disuguhkan kepada khalayak yang itu mengandung unsur erotisme seperti ketika bintang iklan perempuan mengatakan kepada suaminya "kalau tidak mancur kapan enaknya?". Kata-kata tersebut didukung oleh ekspresi menggoda dari sang bintang iklan perempua dan didukung oleh latar waktu dan tempatnya, yakni memekai baju tidur dan laki-laki memakai kaos dalam serta tempat yang digunakan dalam adegan ini adalah sebuah kamar tidur. Apabila dilihat secara sekilas adegan ini menunjukkan bahwa frase yang 
tidak mancur bukanlah pompa air, melainkan terjadi proses hubungan intim yang kurang puas. Karena tempat serta pakaian yang digunakan tidaklah sesuai dengan apa yang menjadi fokus dari pemasaran suatu produk pompa air yang seharusnya berada di dapur atau di kamar mandi yang ada kaitannya dengan air atau pompa air.

\section{New Era Boots}

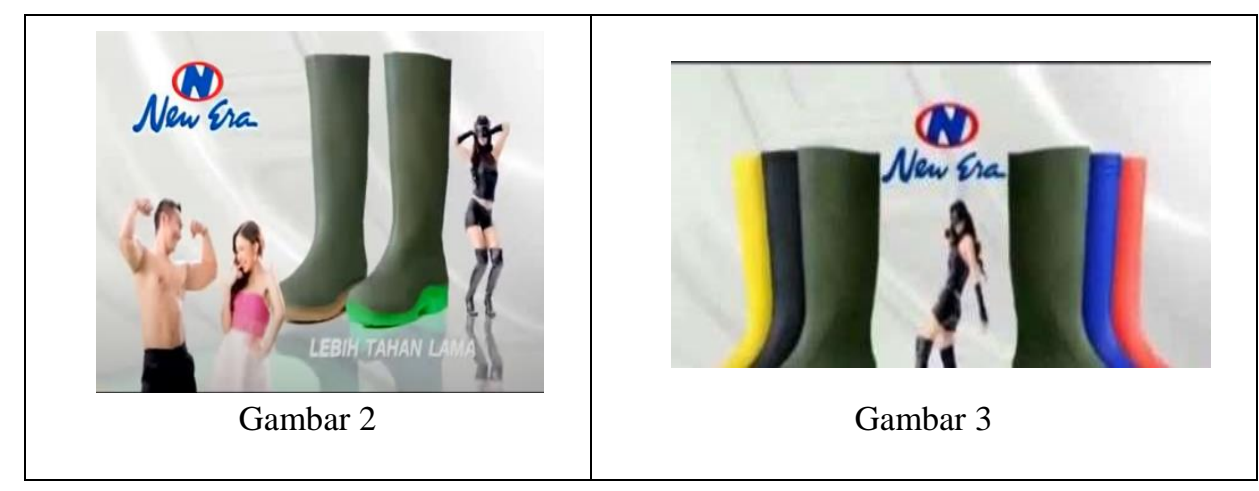

Sebenarnya tidak ada jalan cerita yang pasti dalam iklan New Era Boots ini karena visual yang ditampilkan lebih kepada penggambaran secara eksplisit tentang keunggulan produk. Iklan ini menggunakan 3 orang model, yaitu seorang perempuan berbusana hitam, seorang laki-laki bertelanjang dada dan seorang perempuan memakai busana seksi berwarna merah muda. perempuan menggunakan pakaian ketat serba hitam dan penutup mata, berdiri di antara sepatu boots New Era yang beragam warnanya. Kostum yang digunakan perempuan tersebut jika diperhatikan sekilas mirip dengan kostum tokoh pahlawan dari barat. Perempuan tersebut juga mulai menggoyangkan tubuhnya dengan gemulai.

Dengan menempatkan karakter perempuan seksi ini di antara produk yang ditawarkan sebenarnya tidak ada korelasi langsung mengingat produk ini adalah sebuah sepatu boots yang biasa dipakai saat bekerja di lapangan, berkebun atau saat jalanan becek (hujan). Namun memang pengguna sepatu boots umumnya adalah kaum pria di mana mereka membutuhkan alas kaki yang sifatnya fleksibel dan kuat (seperti yang dinarasikan) saat menghadapi kondisi di atas. Penggunaan tokoh perempuan seksi ini seakan menarik perhatian kaum pria yang mungkin membutuhkan sepatu boots.

Penggunaan model wanita berbaju seksi disini sebenarnya kurang korelatif dengan pesan yang disampaikan oleh pengisi suara tersebut, yaitu "yang penting sol New Era lebih keras". Wanita yang digambarkan sebagai "objek pelengkap" dari peran utamanya yaitu lakilaki. Kalimat yang dilontarkan oleh pengisi suara tersebut juga terkesan ambigu jika harafiahkan memang maksudnya adalah "sol sepatu boots ini lebih keras dibanding dengan sepatu sejenis merk lain". Namun dengan memperlihatkan dua tokoh laki-laki dan perempuan ini (yang notabenya berpakaian dan bergaya kurang senonoh) hanya akan menimbulkan pemikiran negatif kearah pornografi bagi orang-orang yang sekilas menontonnya.

Dengan kalimat "lebih elastis" dan memperlihatkan gerakan gemulai seorang perempuan dengan baju hitam ketat ala tokoh pahlawan, kita sudah bisa mengetahui bagaimana penggambaran eksploitasi daya tarik aspek seksualitas perempuan yang kesannya "mengundang" yang memperbesar asosiasi dan gairah rangsangan seksual para laki-laki yang melihatnya. Dan juga kalimat "lebih kuat" dengan memperlihatkan model laki-laki berotot yang bertelanjang dada serta menggerakkan otot dadanya, memperlihatkan sesuatu yang cukup seronok dan ditambah lagi dengan perempuan yang menggunakan pakaian seksi di sebelahnya. 
3. Iklan Susu Jahe Sido Muncul Versi Sido Susu

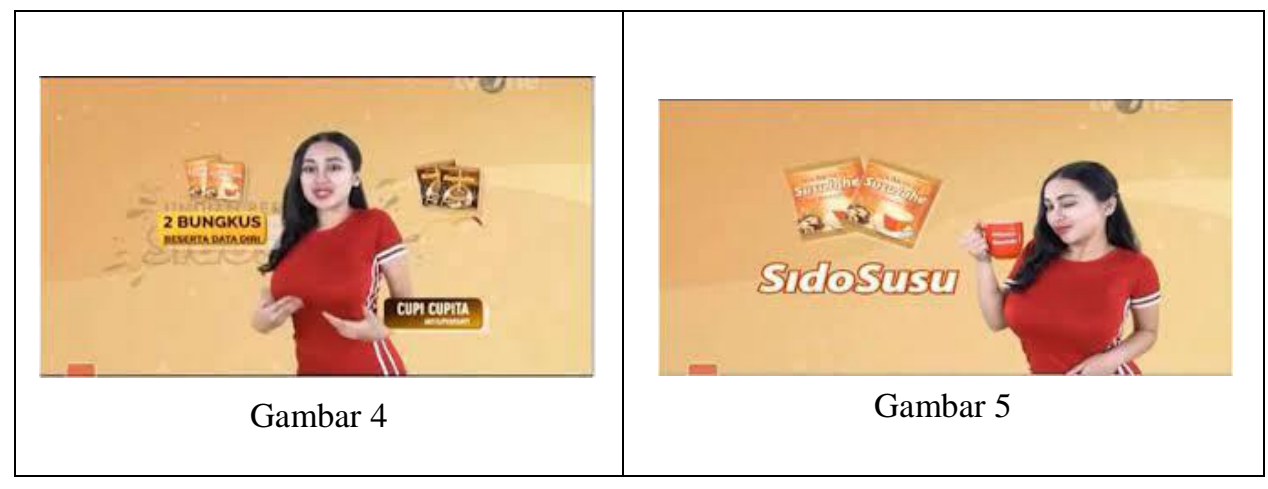

Suatu iklan yang baik akan menawarkan kelebihan dari produk yang ditawarkan, dengan tetap memperhatikan etika. Iklan ini cenderung mengekploitasi perempuan, dengan berfokus pada dada. Ditambah lagi, iklan tersebut tayang di siang hari yang sangat mungkin ditonton anak-anak.

Iklan Susu Jahe Sido Muncul "Sido Susu" yang diperankan oleh seorang wanita berpenampilan seksi merepresentasikan sisi sensualitas perempuan yang masih digunakan dalam industri media. Perempuan dengan standar kecantikan tertentu juga menjadi hal yang lumrah dalam industri periklanan sehingga apa yang ditampilkan oleh iklan ini hanya mewakili sebagian kecil dari realitas masyarakat Indonesia.

Dalam iklan tersebut, sang bintang iklan menggunakan beberapa ekspresi wajah yang sensual, seperti mengedipkan mata sambil mengigit sedikit bibirnya dan bersuara seperti suara yang manja sehingga masuk ke dalam kategori erotis. Bibir yang sedikit terbuka atau menganga dan terlihat seperti tersenyum tipis dapat menimbulkan kesan sensual, menggoda, dan seksi terutama pada perempuan. Fenomena ini telah ditegaskan oleh Allan Pease dan Barbara Pease (2004) bahwa ketika ekspresi wajah dengan bibir yang sedikit menganga akan meningkatkan kesan sensual karena ekspresi tersebut dikaitkan dengan perempuan yang mengalami orgasme saat berhubungan intim, apalagi sang bintang iklan juga sesekali menggoyangkan bagian payudara dan bokongnya. Menggoyangkan bagian payudara dan bokongnya ini menunjukkan bahwa ia ingin memamerkan bentuk payudara serta bokongnya yang besar dan membuat lakilaki dapat berfantasi erotis terhadapnya. Pose membusungkan dada kedepan diartikan sebagai kesan gagah dan percaya diri, tetapi pada iklan ini dengan pakaian berbaju ketatnya menyebabkan membusungkan dada itu sebagai bentuk dari menonjolkan sisi payudaranya yang besar, didukung dengan warna merah yang mencolok dan mengandung makna sensualitas.

\section{Segar Sari Susu Soda}

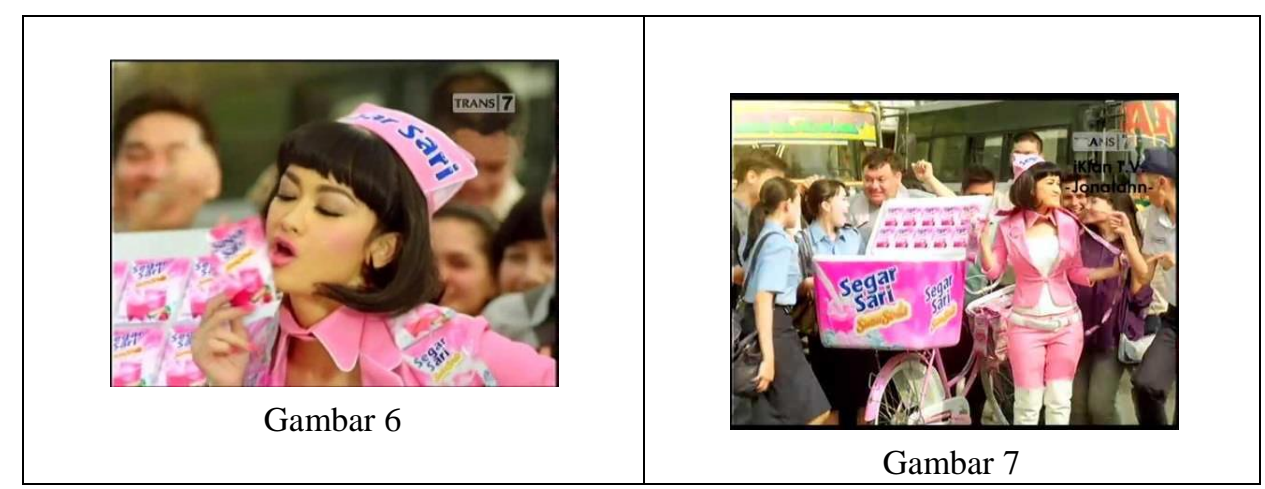


Iklan "Segar Sari Susu Soda" yang menghiasi layar kaca merupakan varian baru dari produk minuman instan "Segar Sari". Dialog merupakan bentuk penyajian kata-kata yang diucapkan oleh pemeran karakter, sebagai gambaran dari logika berpikir, latar belakang serta interaksi tokoh dengan tokoh yang lain. Dialog yang dilakukan oleh model dalam iklan "Segar Sari Susu Soda" adalah dalam bentuk senandung atau nyanyian.

Dalam analisis dialog iklan "Segar Sari Susu Soda", maka desahan seperti "...ahhh... ahhh... ", "....bang.... " merupakan sesuatu yang menumbuhkan sensasi tersendiri di telinga. Padahal bila dilihat melalui kontek yang lebih luas, apalagi dalam sebuah teknik menyanyi ternyata mendesah itu penting untuk mengatur sistem pernapasan dengan volume oksigen yang lebih besar, suara desahan juga bisa membuat orang merespon cepat hal-hal yang tidak terduga, bahkan dapat menghilangkan stres hingga membuat gembira, sebagaimana model iklan mampu membangun suasana ceria dengan senandung dan goyangannya yang membuat tokoh figuran perempuan ikut goyang, dan mengalihkan perhatian para tokoh pemeran pria yang malah terpana dengan goyangan wanita bukan kepada produk yang sedang diiklankan.

Dalam konteks desahan yang dilakukan model pada iklan "Segar Sari Susu Soda" dia menyanyikan senandung dengan. bentuk dialog sebagai berikut: "...Segar sari ahh ahhh...muahh.." (sambil mencium bungkusan minuman Segar Sari Susu Soda, dengan lirikan mata menggoda seakan bungkusan minuman tersebut adalah manusia). "...Susu soda ahhh...." (mengerlipkan sebelah matanya sambil tersenyum nakal). "...Mantap susunya, bang...." (mendesah sambil berjoget disamping pria berpakaian satpam yang menganga terns sambil joget dengan menunjuk-nunjukkan jarinya ke arah dada sang model).

Pengucapan kata "Susu" juga penuh penekanan baik dari ekspresi maupun suara. Dari pelafalan atau pengucapannya mengisyaratkan bahwa kata "Susu" itu bukanlah sebuah minuman yang berasal dari hewan sapi yang diternakkan, tetapi lebih mengarah kepada bagian anatomi tubuh wanita, yaitu payudara. Dengan ditambahkan kata "...mantap susunya bang..." yang diucapkan sambil membusungkan dadanya dan ditambah desahan "bang...", menyatakan bahwa "susu" yang dimaksud oleh model iklan adalah payudaranya.

Bahkan kata tersebut lebih ditekankan lagi dengan slogan iklan "Segar sari Susu Soda" yang diucapkan model dengan sangat menggoda "...Sampe Tumpe-tumpe...", mengarahkan kepada payudara model yang besar. Keberadaan perempuan di media, khususnya iklan masih sangat tereksploitasi ke arah fisik. Iklan "Segar Sari Susu Soda" dalam hal ini, merupakan produk komersil yang ditujukan untuk semua kalangan, dari konsumen anak sampai konsumen dewasa. Namun memilih model iklan dengan label seksi, pemilihan kata, desahan, dan ekspresi, serta gerakan yang mengarah kepada sensualitas dari sosok model ini dapat dengan bebas menghiasi layar kaca konsumen. Kedudukan wanita dalam iklan "Segar Sari Susu Soda" merupakan bentuk penentangan dari segala tekanan emosional, dengan menggunakan kedok atau topeng sensualitas. Dalam iklan semua model sibuk menikmati bentuk fisik wanita yang asyik berjoget, menempatkan tontonan bentuk fisik model utama, dan sosok figuran wanita lain yang turut berjoget sebagai hal yang pokok sedangkan produk yang diiklankan hanya sebagai pelengkap semata..

\section{Iklan Permen Mint Choka}

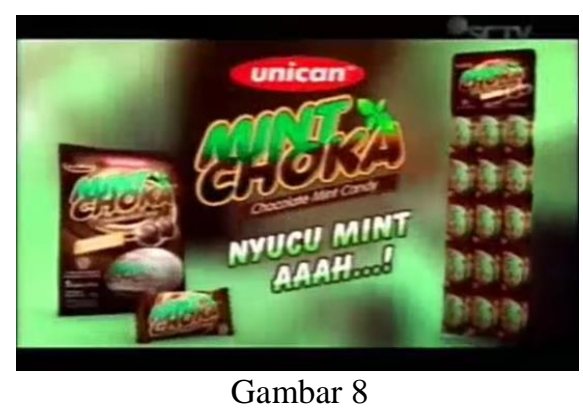

Gambar 8 
Contoh iklan di atas merupakan salah satu contoh iklan permen. Pada iklan ini terdapat kosakata yang tidak sopan dan melecehkan perempuan. Bahkan mengandung unsur erotisme dan memancing para penonton untuk berpikir ke arah yang negatif. Salah satu diksi yang tidak sopan adalah pada awal tayangan terdapat dialog antara laki-laki dan perempuan, pada saat mereka berada di suatu tempat perbelanjan. Seorang perempuan menayakan kepada laki-laki yang ditemaninya "Mau apa? " Laki-laki itu pun menjawab "Mau nyucu” sambil menatap dada perempuan tersebut. Dialog ini dikategorikan mengandung unsur erotisme, baik isi dialognya maupun ekspresi pemeran dalam iklan tersebut.

\section{Iklan KPU (Hoax)}

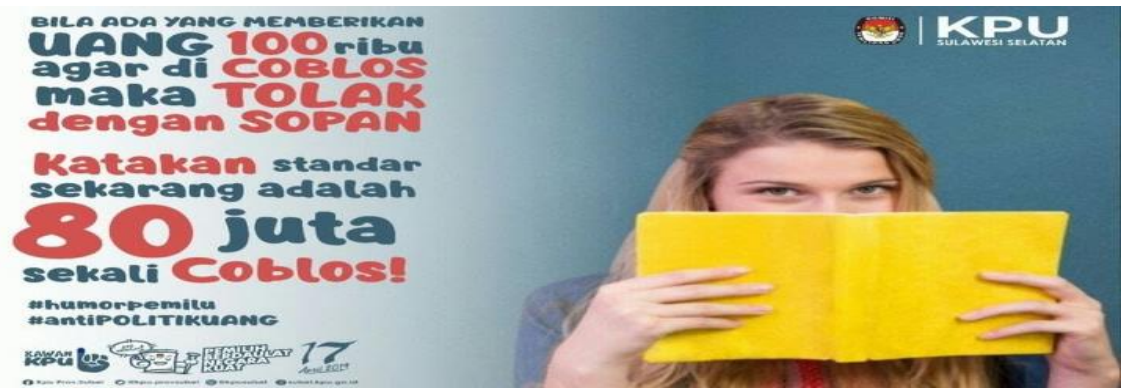

Gambar 9

Beredar iklan yang mengatasnamakan Komisi Pemilihan Umum (KPU) Sulawesi Selatan (Sulsel) yang menyatakan coblos 1 kali 80 juta dengan gambar seorang wanita yang menutupi setengah wajah. Iklan yang beredar di media sosial tersebut dipastikan hoaks. Terlepas dari hoaks atau tidaknya, iklan itu sangatlah tidak sopan atau tidak senonoh, karena di dalam iklan tersebut terdapat kosakata yang bermakna unsur erotisme, lagi pula gambar iklan tersebut adalah seorang artis yang tengah terjerat kasus prostitusi."Katakan standar sekarang adalah 80 juta sekali coblos" ini merupakan kata yang memiliki makna atau mengandung unsur erotisme. Hal itu disebabkan oleh adanya frase "sekali coblos". Akan tetapi sekalipun iklan tersebut memenuhi kriteria sebagai iklan yang erotis, namun (Emi Jaman,2021) dalam penelitiannya menyimpulkan bahwa ternyata banyak juga penonton yang senang menonton iklan yang bernada erotis.

\section{Iklan Rokok}

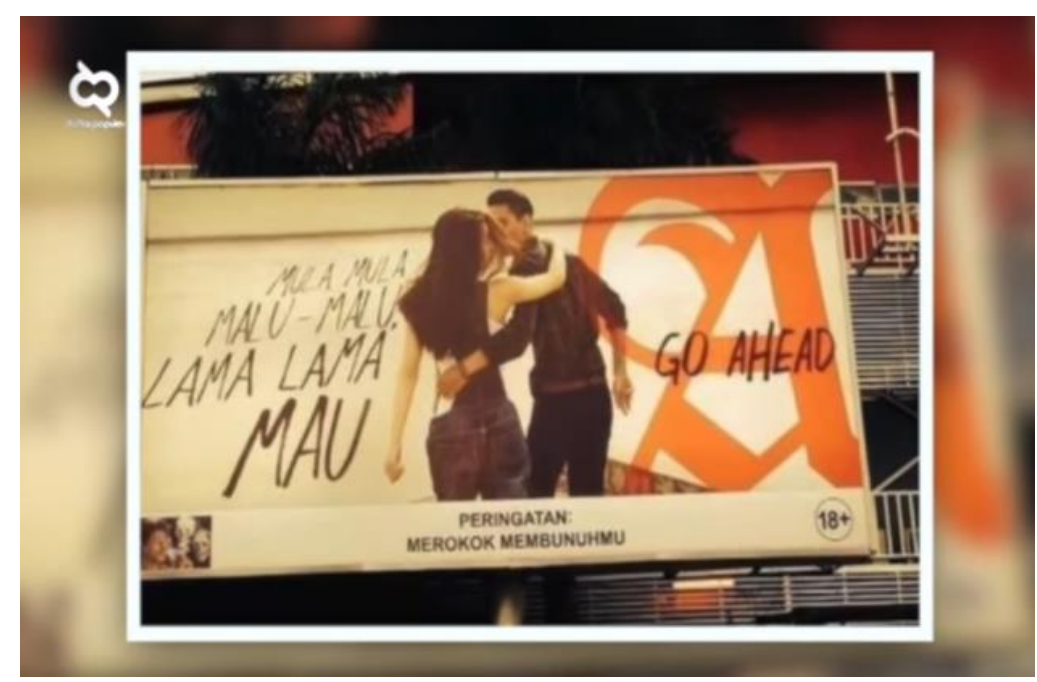

Gambar 10 
Iklan di atas selain dapat dijumpai di media social, dapat pula dilihat di pinggir jalan. Dalam iklan tersebut terdapat tulisan yang berbunyi "Mula-mula malu-malu lama-lama mau". Dalam iklan tersebut terdapat gambar pasangan yang hendak berciuman. Kosakata yang terdapat pada iklan tersebut mengandung unsur erotisme yang dapat mengundang pembaca untuk berpikir macam-macam. Iklan tersebut tidak sepantasnya dipasang pada ranah publik.jika dilihat dari produk yang diiklankan, tampaknya tidak ada korelasi antara kata-kata yang terdapat di dalam iklan tersebut dengan produk salah satu merek rokok. Akan tetapi produsen menginginkan agar produk yang diiklankan tersebut melekat di memori masyarakat sehingga digunakanlah kata-kata atau jargon tertentu yang unik dan ambigu.

\section{PENUTUP}

Bahasa dan iklan adalah dua aspek yang saling melengkapi dan saling membutuhkan. Karena bahasalah sehingga sebuah produk yang diiklankan itu dapat dipahami oleh masyarakat selaku konsemen. Akan tetapi bahasa yang digunakan di media iklan terkesan bermakna erotisme sehingga dapat berpengaruh terhadap penikmat iklan itu sendiri. Maraknya iklan yang menggunakan bahasa yang erotisme dapat berpengaruh terhadap tumbuh kembangnya fisik dan fsikis anak. Adanya unsur-unsur erotisme dalam dunia periklanan membuktikan bahwa KPI atau (Komite Penyiaran Indonesia) belum bekerja secara maksimal dalam mengawasi dunia penyiaran iklan di tanah air. Selama ini masih banyak penontotn, khususnya kaum pria, yang senang menggunakan istilah-istilah atau jargon tertentu yang diambil dari siaran iklan untuk mengungkapkan sesuatu yang berbau pornografi atau pornoaksi. Data yang diuraikan di atas hanyalah sebagian kecil dari sekian banyak iklan yang bernuansa erotis. Namun lepas dari adanya unsur erotis tersebut, ternyata hasil penelitian Emi Jaman (2021) telah membuktikan bahwa ternyata masyarakat di Kabupaten Sidrap senang menonton iklan-iklan yang erotis, baik gambar maupun kata-kata yang digunakannya, karena dianggap sebagai sebuah hiburan

\section{DAFTAR PUSTAKA}

Aprilia, D. R. (2005). Iklan dan Budaya Popular: Pembentukan Identitas Ideologis Kecantikan Perempuan oleh Iklan. Ilmu Komunikasi, 1, 41-68.

Aziz, Z. (2010). Konstruksi Erotisme dalam Karya Eksperimental Media Audio. Visual. Jurnal Komunikator, 2(2), 111-127.

Candrawati, N. L. K. (2019). Analisis Gaya bahasa Iklan Kosmetika dan Obat-obatan Berbahasa Indonesia pada Media Cetak di Bali. Widyadari, 20(2), 175-189. https://doi.org/10.5281/zenodo.3517899

Christianna, Aniendya. (2012). Komodifikasi Fitur Tubuh Perempuan dalam Iklan Produk Makanan (Studi Kasus tvc Timtam Slam dan Timtam Crush), http://repository.petra.ac.id/157471/1/Publikasi-_ 10024_455.pdf.

Jaman, Emmi. 2021. Persepsi Masyarakat Kabupaten Sidrap terhadap Iklan Erotis di Televisi. Tesis. Universitas Muhammadiyah Makassar.

Hapsah, M. (2013). Globalisasi Erotika Media: Studi Kritis Terhadap Etika Seksualitas Iklan Televisi. Jurnal Etika dan Pekerti, 1(2).

Ireneus Lyon Yuniman Bagut. (2019). Penggunaan Bahasa dalam Iklan Minuman di Youtube. Alfabeta: Jurnal Bahasa, Sastra, dan Pengajarannya, 2, 50-62. https://doi.org/10.33503/alfabeta.v2i2.586

Jaya, B., \& Aceh, K. (2018). Representasi Eksploitas Perempuan dalam Iklan New Era Versi Boots pada Media Televisi. Jurnal Ilmiah Mahasiswa FISIP, 3(1), 168-179.

Kristiani, N. (2017). Analisis Pengaruh Iklan di Media Sosial dan Jenis Media Sosial Terhadap Pembentukan Perilaku Konsumtif Mahasiswa di Yogyakarta. Jurnal Bisnis dan Ekonomi (JBE), 24(2), $196-201$. 
Riani, R. (2015). Kajian Wacana Iklan Pada Pesan Singkat (Sms). Ranah: Jurnal Kajian Bahasa, 4(1), 47. https://doi.org/10.26499/rnh.v4i1.24

Saputra, R. (2009). Penggunaan Bahasa Indonesia dalam Iklan Politik. Konfgres Bahasa Indonesia.

Septiani. R. (2014). Analisis Wacana Isi Pesan Iklan Politik Pemilihan Kepada Daerah DKI Jakarta di Media Internet. Jurnal The Messenger, VI(1), 56-65. https://doi.org/10.26623/themessenger.v6i1.170

Sukma, B. P. (2018). Sistem Appraisal pada Slogan dalam Kain Rentang Kampanye Politik Bakal Calon Kepala Daerah Kabupaten dan Kota Bogor. Ranah: Jurnal Kajian Bahasa, 7(2), 132. https://doi.org/10.26499/rnh.v7i2.603

Wahyuningratna, R. N., \& Saputra, W. T. (2018). Ragam Presentasi Iklan Sensual di Televisi (Kajian Semiotika Roland Barthes). Dialektika: Jurnal Ilmu Komunikasi, 5(2), 1-13.

Wahyuningsih, S. (2012). Efek Komodifikasi Perempuan Dalam Iklan : Perspektif Psikologi Komunikasi. Pamator, 5(1), 30-40.

Winata, I. N. (2012). Hegemoni Maskulinitas Dalam Iklan Minuman Berenergi (Analisis Semiotika Extra Joss dan Kuku Bima Ener-G). Jurnal Ilmiah Komunikasi, 3(1), 42-49. http://jurnal.unpand.ac.id/index.php/dinsain/article/view/95/92

Wulandari, K., Sulissusiawan, A., \& Syahrani, A. (2019). Penggunaan Diksi dalam Cerita Fantasi Siswa. Jurnal Pendidikan Dan Pembelajaran Khatulistiwa, 8(11), 1-9.

Yuliantini. T. (2019). Kajian Stelistika terhadap Diksi dalam Kumpulan Puisi Malu (Aku) Jadi Orang Indonesia Karya Taufik Ismail Serta Pemanfaatannya sebagai Bahan Ajar Bahasa indonesia di SMK. Wistara, 11(1), 36-45. 